\title{
Strike-slip faults mediate the rise of crustal-derived fluids and mud volcanism in the deep sea
}

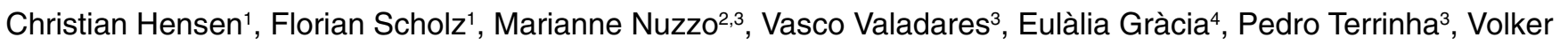 \\ Liebetrau$^{1}$, Norbert Kaul ${ }^{5}$, Sonia Silva ${ }^{3}$, Sara Martínez-Loriente ${ }^{4}$, Rafael Bartolome ${ }^{4}$, Elena Piñero ${ }^{1}$, Vitor H. Magalhães ${ }^{3}$, \\ Mark Schmidt ${ }^{1}$, Stephan M. Weise ${ }^{6}$, Marina Cunha ${ }^{7}$, Ana Hilario ${ }^{7}$, Hector Perea ${ }^{4}$, Lorenzo Rovelli ${ }^{4}$, Klas Lackschewitz ${ }^{1}$ \\ 1GEOMAR Helmholtz-Centre for Ocean Research Kiel, 24148 Kiel, Germany \\ ${ }^{2}$ IGI Ltd., Hallsannery, EX39 5HE Bideford, UK \\ ${ }^{3}$ Portuguese Institute for the Sea and the Atmosphere (IPMA), 1749-077 Lisbon, Portugal \\ ${ }^{4}$ Barcelona Center for Subsurface Imaging, Institut de Ciències del Mar-CSIC, E-08003 Barcelona, Spain \\ ${ }^{5}$ Department of Geosciences, University of Bremen, 28359 Bremen, Germany \\ 6UFZ Helmholtz Centre for Environmental Research, 06120 Halle, Germany \\ 'Department of Biology \& Centre for Environmental and Marine Studies, University of Aveiro, 3810-193 Aveiro, Portugal \\ ${ }^{8}$ The Scottish Association for Marine Science, PA37 1QA Oban, UK
}

\begin{abstract}
We report on newly discovered mud volcanoes located at $\sim 4500 \mathrm{~m}$ water depth $\sim 90 \mathrm{~km}$ west of the deformation front of the accretionary wedge of the Gulf of Cadiz, and thus outside of their typical geotectonic environment. Seismic data suggest that fluid flow is mediated by a $>400-k m$-long strike-slip fault marking the transcurrent plate boundary between Africa and Eurasia. Geochemical data $\left(\mathrm{Cl}, \mathrm{B}, \mathrm{Sr},{ }^{87} \mathrm{Sr} /{ }^{86} \mathrm{Sr}, \delta^{18} \mathrm{O}, \delta \mathrm{D}\right)$ reveal that fluids originate in oceanic crust older than $140 \mathrm{Ma}$. On their rise to the surface, these fluids receive strong geochemical signals from recrystallization of Upper Jurassic carbonates and clay-mineral dehydration in younger terrigeneous units. At present, reports of mud volcanoes in similar deep-sea settings are rare, but given that the large area of transform-type plate boundaries has been barely investigated, such pathways of fluid discharge may provide an important, yet unappreciated link between the deeply buried oceanic crust and the deep ocean.
\end{abstract}

\section{INTRODUCTION}

Fluid seepage and mud volcanism are common at active and passive continental margins (Kopf, 2002); typical driving mechanisms are (1) rapid sedimentation in combination with compaction and tectonic stress, (2) intrusive processes like salt diapirism, (3) dewatering of hydrous minerals, and (4) formation of hydrocarbons. These factors are met in the Gulf of Cadiz, where several kilometer-thick Mesozoic to Holocene sediments accumulated in an accretionary wedge, hosting numerous mud volcanoes (MVs) preferentially at fault intersections (Fig. 1; Magalhães et al., 2012). Proximal to the coast, MV fluids are strongly influenced by clay-mineral dehydration and leaching of Upper Triassic evaporites (Haffert et al., 2013). With increasing distance from the coast, the fluid signature changes, and fluid interaction with the underlying oceanic crust was postulated based on results from the Porto MV (Scholz et al., 2009). The occurrence of MVs located at water depths $>2500 \mathrm{~m}$ is closely tied to the presence of active strike-slip faults (Duarte et al., 2013; Fig. 1), which provide deeply rooted fluid pathways (Hensen et al., 2007). In 2012, R/V Meteor cruise M86/5 was conducted to test hypothesized fluid seepage along deep-rooted strike-slip faults also in distal segments outside the accretionary wedge. Our findings call for a reappraisal of oceanic transform-type faults as fluid conduits and support current hypotheses about ongoing fluid circulation in "aged" upper oceanic crust.

\section{GENERAL OBSERVATIONS}

Acoustic backscatter anomalies recorded during previous bathymetric surveys led to the discovery of three new MVs on cruise M86/5: Abzu, Tiamat, and Michael Ivanov (ATI MVs hereafter; Fig. 1A) at water depths of $\sim 4500 \mathrm{~m}$ at the southern rim of the Horseshoe Valley, 90 $\mathrm{km}$ west of the deformation front of the accretionary wedge (Fig. 1A; Duarte et al., 2013). These MVs are smaller than those found on the accretionary wedge and consist of isolated cones (Fig. 1B) aligned on the Lineament South (LS) trend (Bartolome et al., 2012; Terrinha et al., 2009). The position of the MVs along the LS fault coincides with a seismically active zone with earthquakes of magnitudes $M_{w} \leq 6$ nucleating in the upper mantle between $40 \mathrm{~km}$ and $60 \mathrm{~km}$ depth (Fig. 1A; Geissler et al., 2010). This suggests a fault intersection scenario similar to the situation on the accretionary wedge. Five gravity cores of up to $4.75 \mathrm{~m}$ length were obtained from active fluid emanation sites at ATI and Porto MVs (see Appendix DR1 in the GSA Data Repository ${ }^{1}$ ). Pore water was extracted in intervals $\leq 25 \mathrm{~cm}$ and analyzed for major and minor element composition using standard ana-

${ }^{1}$ GSA Data Repository item 2015124, supporting information on locations, fluid geochemical data, analytical methods, $\mathrm{Sr}$-isotope data of mud clasts, and heat flow measurements, is available online at www.geosociety.org/pubs/ft2015.htm, or on request from editing@geosociety.org or Documents Secretary, GSA, P.O. Box 9140, Boulder, CO 80301, USA. lytical procedures (Appendix DR2; e.g., Scholz et al., 2009). MV sediments typically consist of olive-gray mud breccias with claystone clasts of millimeter to centimeter size, and are highly enriched in $\mathrm{H}_{2} \mathrm{~S}$ and methane. Gas hydrates are found below the zone of anaerobic oxidation of methane (AOM). Dissolved methane escaping from the MV sediment forms plumes above the seafloor and feeds chemosymbiotic assemblages including several species of bivalves and tubeworms (Cunha et al., 2013).

\section{FLUID SOURCES AND IMPLICATIONS}

At ATI MVs, a shallow AOM zone prevails (40-200 cm sediment depth) due to advection of methane-rich fluids. Below the AOM zone, mixing with ambient bottom water is minor so that the chemical composition of rising deep fluids can be studied on samples from this depth, defined as "local endmembers" of a core (e.g., Scholz et al., 2009). Local endmembers from four cores sampled on cruise M86/5 at ATI MVs and one core from Porto MV were selected and compared to previously published (Hensen et al., 2007; Scholz et al., 2009) local endmembers from MVs on the accretionary wedge (Fig. 2; Appendix DR1; distal MVs: Carlos Ribeiro [CRMV], Bonjardim, Porto; proximal MVs: Mercator, Captain Arutyunov [CAMV]).

Fluid data reveal positive and negative correlations of $\delta^{18} \mathrm{O}$ and $\mathrm{Cl}$ versus $\mathrm{B}$ (Fig. 2A) and $\delta^{18} \mathrm{O}$ versus $\delta \mathrm{D}$ (Fig. 2B), respectively. Such trends are typical for clay-mineral dehydration, a major fluid source in the Gulf of Cadiz (Hensen et al., 2007). Clay dehydration causes freshening of fluids (depletion of conservative elements such as $\mathrm{Cl}$ ), a characteristic signal of $\delta^{18} \mathrm{O}$ above and $\delta \mathrm{D}$ below standard seawater composition (Vienna standard mean ocean water, VSMOW), as well as enrichments of boron and other fluid-mobile elements (Dählmann and de Lange, 2003).

Similarly, MV endmembers of Sr (Fig. 2C) and ${ }^{87} \mathrm{Sr} /{ }^{86} \mathrm{Sr}$ ratios (Fig. 2D) were plotted versus Cl. Data from non-ATI MVs in Figure 2C show a similar relationship as in Figures $2 \mathrm{~A}$ and $2 \mathrm{~B}$, 

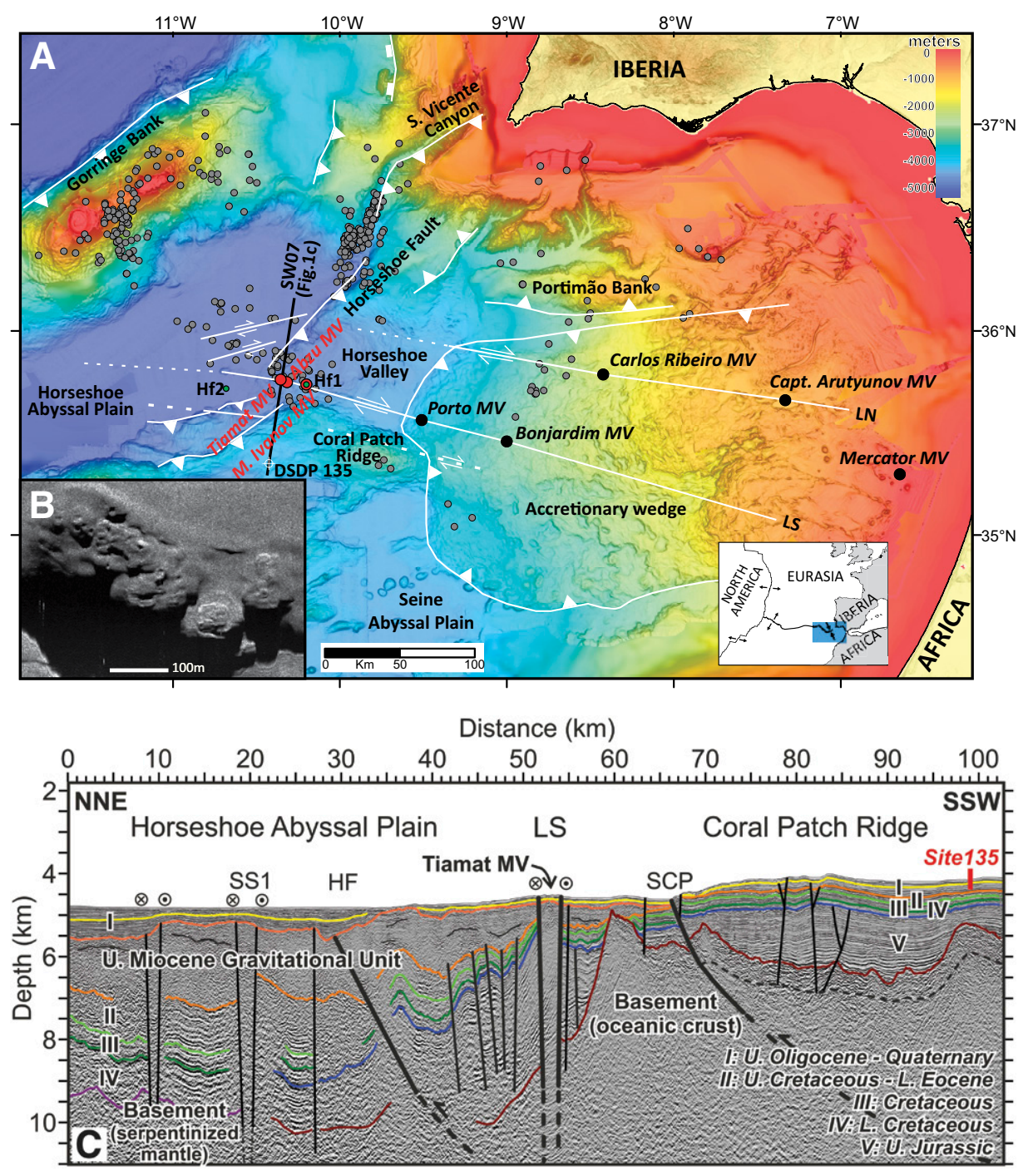

Figure 1. Study area, Gulf of Cadiz, and structural framework. A: Bathymetric map of the southwest lberian margin from $\sim 90 \mathrm{~m}$ digital grids (Zitellini et al., 2009); seismicity data (gray dots) from the NEAREST (Integrated Observation from Near Shore Sources of Tsunami) project temporary deployment; seismic profile SW07 (black line) running across the Lineament South (LS) and Deep Sea Drilling Project (DSDP) site 135; Hf1 and Hf2 (heat flow stations; Appendix DR4 [see footnote 1]). MV-mud volcano. Inset: Plate tectonic setting of the southwest Iberian margin (blue rectangle corresponds to the area depicted in A). B: Detail of a high-resolution sidescan sonar image of Michael Ivanov mud volcano. The entire structure consists of numerous single cones, being typically $<100 \mathrm{~m}$ in diameter. C: Interpreted prestack depth-migrated seismic profile SW07 across the LS (at Tiamat MV), from the Coral Patch Ridge region to the Horseshoe Abyssal Plain. HF-Horseshoe fault; SS1-Strike-slip fault 1 (Martínez-Loriente et al., 2013); SCP-South Coral Patch Ridge fault; LN-Lineament North; U.-Upper; L.-Lower; vertical exaggeration: 5x.

and can be defined by mixing between a certain range of Sr-enriched clay endmembers and sea water (shaded area Fig. 2C). This suggests that $\mathrm{Sr}$ is also derived from clay dehydration. By contrast, ATI MV fluids are clearly offset from this trend. Explaining this offset by mixing of clay-mineral-derived water and seawater would require an unrealistically strong $\mathrm{Sr}$ source in clays. Moreover, $\mathrm{Sr}$ released from clays has a high (radiogenic) ${ }^{87} \mathrm{Sr} /{ }^{86} \mathrm{Sr}$ ratio (Scholz et al., 2009; Appendix DR3) so that a strong Sr input from clays at ATI MVs should cause a positive offset in the isotopic signature, which is not the case (Fig. 2D). Instead, the ${ }^{87} \mathrm{Sr} /{ }^{86} \mathrm{Sr}$ signal of fluids at all distal MVs indicate the decreasing influence of clay-mineral dewatering (Scholz et al., 2009) suggesting a low (less radiogenic) ${ }^{87} \mathrm{Sr} /{ }^{86} \mathrm{Sr}$ ratio of the source at ATI MVs. Two possible sources of $\mathrm{Sr}$ can induce such a low ${ }^{87} \mathrm{Sr} /{ }^{86} \mathrm{Sr}$ signal in this geological setting: deeply buried oceanic crust, and recrystallization of Mesozoic carbonates. Sr concentrations in hydrothermal vent fluids vary between $80 \mu \mathrm{M}$ and $300 \mu \mathrm{M}$ (Butterfield et al., 1994; Campbell et al., 1988; Mottl et al., 2000; Von Damm, 1990), which is below the level measured in most of the MV fluids. Therefore, oceanic crust is unlikely to be the dominant source of $\mathrm{Sr}$ at the ATI MVs. Pore waters of (pelagic) limestones can be enriched in $\mathrm{Sr}$ by $>1 \mathrm{mM}$. The $\mathrm{Sr}$ enrichment is related to recrystallization (Gieskes and Lawrence, 1981) of Sr-rich, meta-stable aragonite to $\mathrm{Sr}$-poor, stable calcite. The ${ }^{87} \mathrm{Sr} /{ }^{86} \mathrm{Sr}$ ratio of fluids affected by this process may be as low as $0.7068\left({ }^{87} \mathrm{Sr} /{ }^{86} \mathrm{Sr}\right.$ of Upper Jurassic seawater and carbonates; Banner, 2004). Seismostratigraphy calibrated with results of nearby Deep Sea Drilling Project (DSDP) Site 135 (Fig. 1) shows an exceptionally thick $(2.5 \mathrm{~km})$ sequence of Upper Jurassic sediments on top of the oceanic basement below the ATI MVs (Fig. 1C; Martínez-Loriente et al., 2013). Evidence from DSDP Site 105 (Hollister et al., 1972), the western Atlantic counterpart to Site 135, suggests that Upper Jurassic sediments in the study area are indeed pelagic limestones.

To further explore how potential sources may affect the MV fluid compositions, we examine a plot of $\mathrm{Sr} / \mathrm{B}$ versus ${ }^{87} \mathrm{Sr} /{ }^{86} \mathrm{Sr}$ (Fig. 3). This combination of parameters allows for a clear discrimination between (1) clay (strongly radiogenic $\left.{ }^{87} \mathrm{Sr} /{ }^{86} \mathrm{Sr}\right)$, (2) carbonates $\left({ }^{87} \mathrm{Sr} /{ }^{86} \mathrm{Sr}\right.$ between present-day and the Late Jurassic Ocean; high Sr/B), and (3) oceanic crust (welldefined, strongly non-radiogenic ${ }^{87} \mathrm{Sr} /{ }^{86} \mathrm{Sr}$ ) as potential sources. The fluid composition of the proximal MVs is close to the suggested endmember of clay-mineral dewatering, while that of ATI MVs shows a strong imprint of recrystallization of Upper Jurassic carbonates (Fig. 3). The distal, non-ATI MVs plot within the binary mixing field of "clay" and "crust", suggesting a negligible influence of carbonate recrystallization there. This interpretation is in line with stratigraphic evidence for the subsurface extension of Upper Jurassic sediments (Fig. 4). Consequently, only ATI MVs receive the strong signal from carbonate recrystallization.

Unlike clay minerals, sedimentary carbonates do not store water in their lattice, and the process of recrystallization only enriches ambient pore waters in Sr. Therefore, an additional transport mechanism is required to carry the signal of carbonate recrystallization to the seafloor. Freshwater release from clay is presumably low in carbonate-rich sediments. In addition, clay-mineral dehydration occurs at temperatures between $60{ }^{\circ} \mathrm{C}$ and $150{ }^{\circ} \mathrm{C}$ (Hensen et al., 2007), which translates into sub-seafloor depths of 1-3 km (geothermal gradient 45-50 $\mathrm{K} \mathrm{km}{ }^{-1}$; Appendix DR4; Grevemeyer et al., 2009). Thus, there is only a limited overlap with the Upper Jurassic sediments $(2-4.5 \mathrm{~km}$ sub-seafloor depth). As the Upper Jurassic unit corresponds to the deepest sedimentary deposits located right above the oceanic crust, only a scenario where crustal-derived fluids carry the geochemical signals upward (mixing of all three sources in Fig. 3) can explain observed 

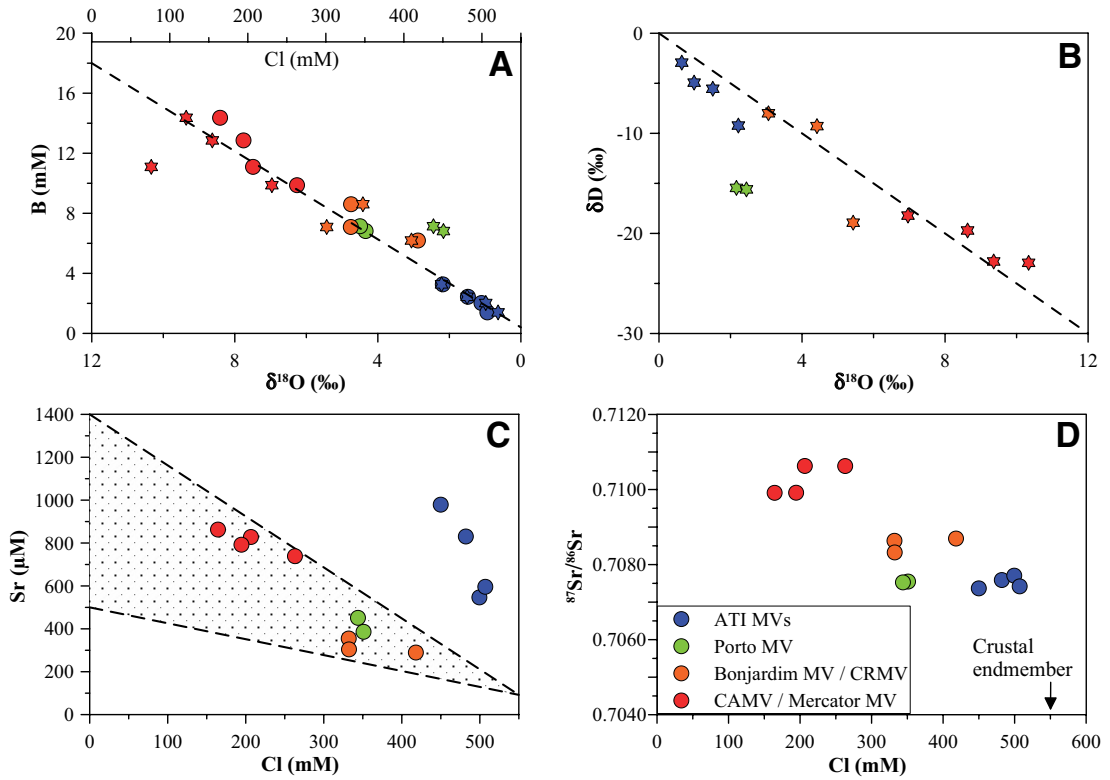

Figure 2. Endmember plots for various mud volcano (MV) fluids. A: $\delta^{18} O$ versus boron (stars) and $\mathrm{Cl}$ versus boron. B: $\delta^{18} \mathrm{O}$ versus $\delta \mathrm{D}$ (stars). ATI MVs-Abzu, Tiamat, and Michael Ivanov MVs; CRMV-Carlos Ribeiro MV; CAMV-Captain Arutyunov MV. Dashed lines in A and B indicate trends with suggested endmember concentrations of clay-mineral-derived water $\left(B=18, C l=0, \delta^{18} O=12 ; \delta D=-30\right)$ and seawater $\left(B=0.4, C l=550, \delta^{18} O=0 ; \delta D=0\right)$. C: $C l$ versus Sr. Shaded field between the dashed lines defines the mixing area between minimum and maximum $\mathrm{Sr}$ endmembers at $\mathrm{Cl}=0$ and seawater. $\mathrm{D}: \mathrm{Cl}$ versus ${ }^{87} \mathrm{Sr} /{ }^{86} \mathrm{Sr}$. Note that $\mathrm{Cl}$-concentrations for samples from Mercator MV and Captain Arutyunov MV (CAMV) in A were corrected using the equation of Hensen et al. (2007), because fluids at those sites were affected by salt dissolution (see Appendix DR1 in the Data Repository [see footnote 1]).

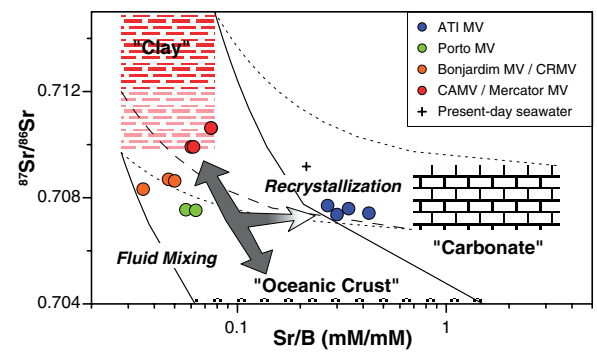

Figure 3. Endmembers of mud volcano (MV) fluids (symbols) and assumed fluid sources (boxes). Ranges were derived as follows. Clay-mineral dewatering: Lower and upper boundary of ${ }^{87} \mathrm{Sr} /{ }^{86} \mathrm{Sr}=0.7094-0.7150$ (derived from clay clasts; see Appendix DR3 [see footnote 1]; Scholz et al., 2009), Sr/B from linear extrapolation of data to $\mathrm{Cl}=0$ mM (Figs. 2A and 2C). Carbonates: ${ }^{87} \mathrm{Sr} /{ }^{86} \mathrm{Sr}$ $=0.7068-0.7092$ (range from Late Jurassic to contemporaneous seawater), $\mathrm{Sr}=300$ $1500 \mu \mathrm{M}, \mathrm{B}=\mathbf{0 . 4 3} \mathrm{mM}$ (seawater). Crustal derived fluids: ${ }^{87} \mathrm{Sr} /{ }^{86} \mathrm{Sr}=0.7040, \mathrm{Sr} / \mathrm{B} \mathrm{min} /$ max derived from Butterfield et al. (1994), Campbell et al. (1988), Mottl et al. (2000), Von Damm (1990). Lines indicate two-endmember mixing of reservoirs: solid (claycrust), stippled (clay-carbonate). Hatched line for clay-carbonate mixing uses the average value of all clast samples $\left({ }^{87} \mathrm{Sr} /{ }^{86} \mathrm{Sr}=\right.$ 0.7120 ) and thus the most likely lower endmember value of clay clasts (indicated by faded red color below this value). ATI MVsAbzu, Tiamat, and Michael Ivanov MVs; CRMV-Carlos Ribeiro MV; CAMV-Captain Arutyunov MV. this location. Negative shifts in $\delta^{18} \mathrm{O}$ i.e., opposite to the effect observed during clay dehydration, are typical for mineral hydration processes such as the alteration of volcanic ash or oceanic crust (Gieskes and Lawrence, 1981). This trend is hardly visible at ATI MVs, likely due to the strong imprint of carbonate recrystallization favoring the formation of ${ }^{18} \mathrm{O}$-enriched fluids at elevated temperatures (Lawrence et al., 1975) and counteracting any negative crustalderived $\delta^{18} \mathrm{O}$ signal.

In spite of the clear geochemical evidence, the precise mechanism driving fluid flow remains elusive. The major strike-slip fault (LS) provides a deep-reaching, permeable conduit that serves as pathway for ascending fluids. Strikeslip faulting has been previously suggested as a mechanism for the release of overpressure, eventually leading to pulses of fluid flow (Mazzini et al., 2009; Sibson, 1987; Viola et al., 2005). Deep seismic activity in the vicinity of ATI MVs (Fig. 1) indeed supports this hypothesis. In addition, pore water convection, related to the existence of local basement highs (e.g., Coral Patch Ridge; Figs. 1 and 4), could provide an alternative scenario of crustal-derived flow. To date, examples for fluid convection are mainly reported from the eastern Pacific, where pore fluids circulate through interconnected seamounts in young oceanic crust (Fisher et al., 2003).

\section{CONCLUSIONS}

Our findings confirm that seismogenic strikeslip faults provide pathways for deep-seated fluids, sustaining mud volcanism even in abyssal regions, outside areas of rapid sediment accumulation. Moreover, strike-slip faults tap fluid sources in oceanic crust older than $140 \mathrm{Ma}$, contradicting previous assumptions that fluid circulation terminates at a crustal age of ca. 65 $\pm 10 \mathrm{Ma}$ (Stein et al., 1995). Although the exact mechanism remains poorly constrained, our data provide evidence for fluid flow within old oceanic crust in an area of strong topographic contrasts and deep basement faults as suggested by Von Herzen (2004). Interestingly, MVs expel-

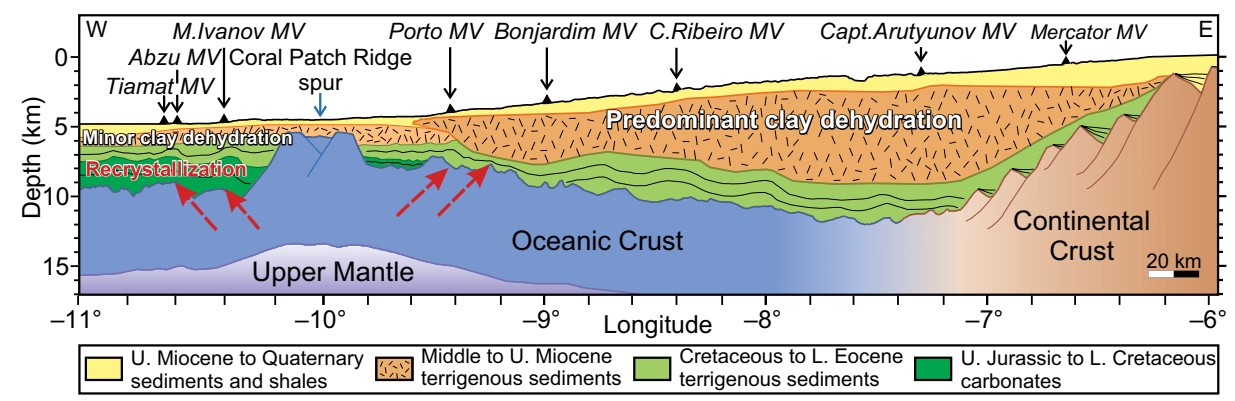

Figure 4. Regional synthetic (west to east) cross section from the continental shelf to the deep Horseshoe Basin north of Coral Patch Ridge (roughly following the Lineament South [LS]) illustrating major sources and processes affecting the fluid composition of distal mud volcanoes (MVs) in the Gulf of Cadiz. The largest potential for clay-mineral dehydration exists within the suitable temperature/depth range in the Middle to Upper Miocene terrigeneous units. MVs are projected along the profile. Note that Coral Patch Ridge is a prominent basement elevation appearing as buried spur and corresponds to a significant elevation of the seafloor, south of LS (Fig. 1). U.-Upper; L.-Lower. Vertical exaggeration: $\sim 5 x$. 
ling geochemically distinct fluids off the Barbados Accretionary Prism (Godon et al., 2004) are found in a tectonic setting comparable to that in the Gulf of Cadiz. Those are aligned along a major fracture zone and it was suggested that mud volcanism was initiated by changes in plate motion along this fracture (Sumner and Westbrook, 2001). Globally, transform-type plate boundaries are of similar length as divergent and convergent plate boundaries (Bird, 2003) and the latter are known for intense vent and seep activity. We suggest that transform-type plate boundaries and fracture zones may also provide important pathways for fluid exchange between the lithosphere and the deep ocean, and hence deserve more intense future exploration to evaluate their role in terms of heat and element exchange.

\section{ACKNOWLEDGMENTS}

We thank Captain Schwarze and his crew onboard $\mathrm{R} / \mathrm{V}$ Meteor for excellent support at sea. We are indebted to our colleagues A. Bleyer, B. Domeyer, A. Kolevica, and R. Surberg for lab support. A great "thank you" to the AUV Abyss team at GEOMAR. A. Reitz and M. Haeckel are thanked for their support and helpful discussions. The manuscript benefitted from constructive reviews of M. Huuse, F. Meneghini, G. Viola, and an anonymous reviewer. Cruise M 86/5 was funded by the German Research Foundation (TransFlux grant) with additional support by SHAKE, SWIMGLO, MODELINK, and FLOWS (EU-COST, ES 1301) projects.

\section{REFERENCES CITED}

Banner, J.L., 2004, Radiogenic isotopes: systematics and applications to earth surface processes and chemical stratigraphy: Earth-Science Reviews, v. 65 , p. 141-194, doi:10.1016/S0012-8252(03) 00086-2.

Bartolome, R., Gràcia, E., Stich, D., Martínez-Loriente, S., Klaeschen, D., Mancilla, F., Lo Iacono, C., Dañobeitia, J.J., and Zitellini, N., 2012, Evidence for active strike-slip faulting along the Eurasia-Africa convergence zone: Implications for seismic hazard in the southwest Iberian margin: Geology, v. 40, p. 495-498, doi:10.1130 /G33107.1.

Bird, P., 2003, An updated digital model of plate boundaries: Geochemistry Geophysics Geosystems, v. 4, p. 1027, doi:10.1029/2001GC000252.

Butterfield, D.A., McDuff, R.E., Mottl, M.J., Lilley, M.D., Lupton, J.E., and Massoth, G.J., 1994, Gradients in the composition of hydrothermal fluids from the Endeavour segment vent field: Phase separation and brine loss: Journal of Geophysical Research, v. 99, p. 9561-9583, doi: 10.1029/93JB03132.

Campbell, A.C., et al., 1988, Chemistry of hot springs on the Mid-Atlantic Ridge: Nature, v. 335, p. 514-519, doi:10.1038/335514a0.

Cunha, M.R., Rodrigues, C.F., Génio, L., Hilário, A., Ravara, A., and Pfannkuche, O., 2013, Macrofaunal assemblages from mud volcanoes in the Gulf of Cadiz: abundance, biodiversity and diversity partitioning across spatial scales: Biogeosciences, v. 10, p. 2553-2568, doi:10.5194 /bg-10-2553-2013.

Dählmann, A., and de Lange, G.J., 2003, Fluidsediment interactions at Eastern Mediterranean mud volcanoes: a stable isotope study from ODP Leg 160: Earth and Planetary Science
Letters, v. 212, p. 377-391, doi:10.1016/S0012 $-821 \mathrm{X}(03) 00227-9$.

Duarte, J.C., Rosas, F.M., Terrinha, P., Schellart, W.P., Boutelier, D., Gutscher, M.-A., and Ribeiro, A., 2013, Are subduction zones invading the Atlantic? Evidence from the southwest Iberia margin: Geology, v. 41, p. 839-842, doi:10.1130 /G34100.1.

Fisher, A., et al., 2003, Hydrothermal recharge and discharge across $50 \mathrm{~km}$ guided by seamounts on a young ridge flank: Nature, v. 421, p. 618-621, doi:10.1038/nature01352.

Geissler, W.H., Matias, L., Stich, D., Carrilho, F., Jokat, W., Monna, S., IbenBrahim, A., Mancilla, F., Gutscher, M.A., Sallarès, V., and Zitellini, N., 2010, Focal mechanisms for sub-crustal earthquakes in the Gulf of Cadiz from a dense OBS deployment: Geophysical Research Letters, v. 37, L18309, doi:10.1029/2010GL044289.

Gieskes, J.M., and Lawrence, J.R., 1981, Alteration of volcanic matter in deep-sea sediments: evidence from the chemical composition of interstitial waters from deep-sea drilling cores: Geochimica et Cosmochimica Acta, v. 45, p. 1687-1703, doi:10.1016/0016-7037(81)90004-1.

Godon, A., Jendrzejewski, N., Castrec-Rouelle, M., Dia, A., Pineau, F., Boulegue, J., and Javoy, M., 2004, Origin and evolution of fluids from mud volcanoes in the Barbados accretionary complex: Geochimica et Cosmochimica Acta, v. 68, p. 2153-2165, doi:10.1016/j.gca.2003.08.021.

Grevemeyer, I., Kaul, N., and Kopf, A., 2009, Heat flow anomalies in the Gulf of Cadiz and off Cape San Vincente, Portugal: Marine and Petroleum Geology, v. 26, p. 795-804, doi:10.1016/j .marpetgeo.2008.08.006.

Haffert, L., Haeckel, M., Liebetrau, V., Berndt, C., Hensen, C., Nuzzo, M., Reitz, A., Scholz, F., Schönfeld, J., Perez-Garcia, C., and Weise, S.M., 2013, Fluid evolution and authigenic mineral paragenesis related to salt diapirism - The Mercator mud volcano in the Gulf of Cadiz: Geochimica et Cosmochimica Acta, v. 106, p. 261-286, doi:10.1016/j.gca.2012.12.016.

Hensen, C., Nuzzo, M., Hornibrook, E., Pinheiro, L.M., Bock, B., Magalhães, V.H., and Brückmann, W., 2007, Sources of mud volcano fluids in the Gulf of Cadiz - indications for hydrothermal imprint: Geochimica et Cosmochimica Acta, v. 71, p. 1232-1248, doi:10.1016/j.gca 2006.11.022.

Hollister, C.D., Ewing, J.I., Habib, D., Hathaway, J.C., Lancelot, Y., Luterbacher, H., Paulus, F.J., Poag, C.W., Wilcoxon, J.A., and Worstell, P., 1972, Site 105 - Lower continental rise hills: Deep Sea Drilling Program, Initial Reports Volume 11: Washington, D.C., Deep Sea Drilling Program, p. 219-312.

Kopf, A., 2002, Significance of mud volcanism: Reviews of Geophysics, v. 40, p. 1-52, doi: 10.1029/2000RG000093.

Lawrence, J.R., Gieskes, J.M., and Broecker, W.S., 1975, Oxygen isotope and cation composition of DSDP pore waters and the alteration of Layer II basalts: Earth and Planetary Science Letters, v. 27, p. 1-10, doi:10.1016/0012-821X (75)90154-5.

Magalhães, V.H., et al., 2012, Formation processes of methane-derived authigenic carbonates from the Gulf of Cadiz: Sedimentary Geology, v. 243-244, p. 155-168, doi:10.1016/j .sedgeo.2011.10.013.

Martínez-Loriente, S., Gràcia, E., Bartolome, R., Sallarès, V., Connors, C., Perea, H., Lo Iacono, C., Klaeschen, D., Terrinha, P., Dañobeitia, J.J., and Zitellini, N., 2013, Active deforma- tion in old oceanic lithosphere and significance for earthquake hazard: Seismic imaging of the Coral Patch Ridge area and neighboring abyssal plains (SW Iberian Margin): Geochemistry Geophysics Geosystems, v. 14, p. 2206-2231, doi:10.1002/ggge.20173.

Mazzini, A., Nermoen, A., Krotkiewski, M., Podladchikov, Y., Planke, S., and Svensen, H., 2009, Strike-slip faulting as a trigger mechanism for overpressure release through piercement structures. Implications for the Lusi mud volcano, Indonesia: Marine and Petroleum Geology, v. 26, p. 1751-1765, doi:10.1016/j .marpetgeo.2009.03.001.

Mottl, M.J., Wheat, C.G., and Monnin, C., 2000, Site 1023-1032: Data report: Trace elements in porewater, eastern flank of the Juan de Fuca Ridge: Proceedings Ocean Drilling Program, Scientific results, Volume 168: College Station, Texas, Ocean Drilling Program, p. 105-109.

Scholz, F., Hensen, C., Reitz, A., Romer, R.L., Liebetrau, V., Meixner, A., Weise, S.M., and Haeckel, M., 2009, Isotopic evidence $\left({ }^{87} \mathrm{Sr} /{ }^{86} \mathrm{Sr}\right.$, $\left.\delta^{7} \mathrm{Li}\right)$ for alteration of the oceanic crust at deeprooted mud volcanoes in the Gulf of Cadiz, NE Atlantic Ocean: Geochimica et Cosmochimica Acta, v. 73, p. 5444-5459, doi:10.1016/j.gca .2009.06.004

Sibson, R.H., 1987, Earthquake rupturing as a mineralizing agent in hydrothermal systems: Geology, v. 15, p. 701-704, doi:10.1130/0091-7613 (1987)15<701:ERAAMA>2.0.CO;2.

Stein, C.A., Stein, S., and Pelayo, A., 1995, Heat flow and hydrothermal circulation, in Humphris, S.E., et al., eds., Seafloor Hydrothermal Systems: Physical, Chemical, Biological, and Geological Interactions, Volume 91: Washington DC, American Geophysical Union, p. 425-445.

Sumner, R.H., and Westbrook, G.K., 2001, Mud diapirism in front of the Barbados accretionary wedge: the influence of fracture zones and North America - South America plate motions: Marine and Petroleum Geology, v. 18, p. 591-613, doi:10.1016/S0264-8172(01)00010-1.

Terrinha, P., et al., 2009, Morphotectonics and strain partitioning at the Iberian-Africa plate boundary from multibeam and seismic reflection data: Marine Geology, v. 267, p. 156-174, doi: 10.1016/j.margeo.2009.09.012.

Viola, G., Andreoli, M., Ben-Avraham, Z., Stengel, I., and Reshef, M., 2005, Offshore mud volcanoes and onland faulting in southwestern Africa: neotectonic implications and constraints on the regional stress field: Earth and Planetary Science Letters, v. 231, p. 147-160, doi:10.1016/j .eps1.2004.12.001.

Von Damm, K.L., 1990, Seafloor hydrothermal activity: Black smoker chemistry and chimneys: Annual Review of Earth and Planetary Sciences, v. 18, p. 173-204, doi:10.1146/annurev .ea.18.050190.001133.

Von Herzen, R., 2004, Evidence for continuing hydrothermal circulation in old crust, in Davis, E.E., and Elderfield, H., eds., Hydrogeology of the Oceanic Lithosphere: Cambridge, UK, Cambridge University Press, p. 414-447.

Zitellini, N., et al., 2009, The quest for the Africa-Eurasia plate boundary west of the Strait of Gibraltar: Earth and Planetary Science Letters, v. 280, p. 13-50, doi:10.1016/j.epsl.2008.12.005.

Manuscript received 14 October 2014

Revised manuscript received 19 December 2014

Manuscript accepted 20 January 2015

Printed in USA 


\section{Geology}

\section{Strike-slip faults mediate the rise of crustal-derived fluids and mud volcanism in the deep sea}

Christian Hensen, Florian Scholz, Marianne Nuzzo, Vasco Valadares, Eulàlia Gràcia, Pedro Terrinha, Volker Liebetrau, Norbert Kaul, Sonia Silva, Sara Martínez-Loriente, Rafael Bartolome, Elena Piñero, Vitor H. Magalhães, Mark Schmidt, Stephan M. Weise, Marina Cunha, Ana Hilario, Hector Perea, Lorenzo Rovelli and Klas Lackschewitz

Geology 2015;43;339-342

doi: $10.1130 / G 36359.1$

Email alerting services

Subscribe

Permission request click www.gsapubs.org/cgi/alerts to receive free e-mail alerts when new articles cite this article

click www.gsapubs.org/subscriptions/ to subscribe to Geology

click http://www.geosociety.org/pubs/copyrt.htm\#gsa to contact GSA

Copyright not claimed on content prepared wholly by U.S. government employees within scope of their employment. Individual scientists are hereby granted permission, without fees or further requests to GSA, to use a single figure, a single table, and/or a brief paragraph of text in subsequent works and to make unlimited copies of items in GSA's journals for noncommercial use in classrooms to further education and science. This file may not be posted to any Web site, but authors may post the abstracts only of their articles on their own or their organization's Web site providing the posting includes a reference to the article's full citation. GSA provides this and other forums for the presentation of diverse opinions and positions by scientists worldwide, regardless of their race, citizenship, gender, religion, or political viewpoint. Opinions presented in this publication do not reflect official positions of the Society.

\section{Notes}

(c) 2015 Geological Society of America

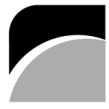

THE

GEOLOGICAL

SOCIETY

OF AMERICA 